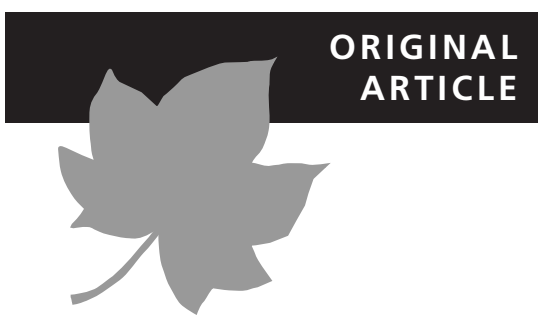

\title{
The curse of taxonomic uncertainty in biogeographical studies of free-living terrestrial protists: a case study of testate amoebae from Amsterdam Island
}

\author{
T. J. Heger ${ }^{1,2,3,4 \star}$, E. A. D. Mitchell ${ }^{1,2,3}$, P. Ledeganck ${ }^{5}$, S. Vincke ${ }^{5}$, \\ B. Van de Vijver ${ }^{6}$ and L. Beyens ${ }^{5}$
}

${ }^{1}$ WSL, Swiss Federal Institute for Forest, Snow and Landscape Research, Ecosystem Boundaries Research Unit, Wetlands Research Group, Station 2, Lausanne, Switzerland, ${ }^{2}$ École Polytechnique Fédérale de Lausanne (EPFL), Laboratory of Ecological Systems, Station 2, Lausanne, Switzerland, ${ }^{3}$ Plant and Soil Laboratory, Institute of Biology, University of Neuchâtel, Neuchâtel, Switzerland, ${ }^{4}$ Department of Zoology and Animal Biology, Molecular Systematics Group, Sciences III, University of Geneva, Geneva, Switzerland, ${ }^{5}$ Department of Biology, Research Group of Polar Biology, Limnology and Geomorphology, Universiteit Antwerpen, Campus Drie Eiken, Universiteitsplein 1, Wilrijk, Belgium and ${ }^{6}$ Department of Cryptogamy (Bryophyta and Thallophyta), National Botanic Garden of Belgium, Domein van Bouchout, Meise, Belgium
${ }^{*}$ Correspondence: Thierry Heger, WSL, Swiss Federal Institute for Forest, Snow and Landscape Research, Ecosystem Boundaries Research Unit, Wetlands Research Group, Station 2, CH-1015 Lausanne, Switzerland.

E-mail: thierry.heger@epfl.ch

\begin{abstract}
Aim A current debate in microbial biogeography contrasts two views concerning the distribution of free-living microorganisms. The first view assumes a ubiquitous distribution, while the second assumes that at least some species have limited geographical distributions. We tested for limited geographical distributions by identifying testate amoebae morphospecies from an extremely remote oceanic island where the potential for endemism is high.
\end{abstract}

Location Amsterdam Island, Indian Ocean.

Methods Sixty moss and water samples collected from the top of the volcano to the lowland were investigated for their testate amoeba content. Due to taxonomic uncertainties among the Argynnia (Nebela) dentistoma species complex (including A. antarctica), we also performed light and scanning electron microscopy investigations on the shell ultrastructure and biometric analyses on several specimens of this taxon.

Results We identified a total of 43 testate amoeba taxa belonging to 15 genera. Only four testate amoeba taxa had previously been recorded on this island. Testate amoeba communities of Amsterdam Island are dominated by cosmopolitan ubiquitous euglyphid taxa such as Trinema lineare, Assulina muscorum and Corythion dubium. The length and width ranges for Argynnia dentistoma on Amsterdam Island overlap with other records of this species and of $A$. antarctica, suggesting that $A$. antarctica is not a distinct taxon.

Main conclusions Although Amsterdam Island is among the most remote islands in the world, an extensive inventory of testate amoeba morphospecies provided no clear evidence for endemism. On the one hand, our detailed morphometric analysis of the A. dentistoma complex revealed that $A$. antarctica, a morphospecies previously suggested to display endemism, cannot be confidently distinguished from the cosmopolitan morphospecies A. dentistoma. On the other hand, five morphotaxa could not be identified with certainty and might represent new species, potentially with limited distribution. These examples illustrate how taxonomic uncertainties undermine biogeographical studies of testate amoebae. In order to allow better interpretation of morphologybased testate amoeba distribution data, an assessment of genetic diversity among and within morphotaxa in relation to geographical distance for some common testate amoebae should be given high priority.

\section{Keywords}

Amsterdam Island, biogeography, cosmopolitan distribution, endemism, Indian Ocean, microorganisms, taxonomy, testate amoebae. 


\section{INTRODUCTION}

The current (and long-lasting) debate within microbial biogeography contrasts two opposing views concerning the distribution of microorganisms. The first view (the so-called 'ubiquity theory') assumes that all microorganisms are ubiquitous because their abundance is very large (which sustains global dispersal) (Finlay \& Clarke, 1999; Finlay et al., 1999, 2001), while the second view (the so-called 'biogeography theory' or 'moderate endemicity distribution theory') assumes that at least some of them have limited geographical distributions (Foissner, 1997, 1998, 1999, 2008; Stoeck et al., 2007; Vyverman et al., 2007). Testate amoebae provide evidence for both views, and are a good model group for studies of the biogeography of free-living protists. The available data indeed suggest that these protozoa include (1) species small enough to be passively transported over long distances, and (2) species that are large enough to make this rather unlikely (Wilkinson, 1994, 2001; Smith \& Wilkinson, 2007).

In the Southern Hemisphere, the testate amoeba diversity of several remote islands located within medium-to-high latitudes have been investigated extensively, mostly over the past few decades [Iles Kerguelen: Bonnet (1981); Iles Crozet: Vincke et al. (2004a,b,c); Vincke (2006); Marion Island: Penard (1911); Grospietsch (1971); South Georgia: Smith (1982), Beyens et al. (1995); Vincke et al. (2006); Ascension Island: Wilkinson \& Smith (2006)]. These studies all revealed a large majority of cosmopolitan species. However, a few species showing a more restricted distribution were also recorded. For example, Apodera vas, a species reported only from the Southern Hemisphere and the tropics (Smith \& Wilkinson, 2007), was observed on several sub-Antarctic islands. Endemism was suggested for a second species, Argynnia (Nebela) antarctica, observed only on Marion Island (Grospietsch, 1971). However, because of the high morphological similarity of this species with Argynnia dentistoma Penard, its exact taxonomic status and hence its possible endemic distribution needs to be confirmed using biometric and/or molecular analysis.

Taxonomic uncertainty is one of the principal sources of concern with respect to the ubiquity vs. endemism debate (Mitchell \& Meisterfeld, 2005). For example, possible taxonomic confusion with closely related species makes it impossible at the moment to assess if A. antarctica should be considered to be an endemic species on Marion Island. Moreover, the 'force-fitting' of European and North American names to specimens from other regions may lead to inaccurate distribution records. Such a bias has been shown to explain at least part of the initial underestimation of diatom endemism in Antarctica (Sabbe et al., 2003). Another problem that may also lead to inaccurate conclusions on biogeographical patterns is the uneven sampling efforts across different regions of the world (Foissner, 2006).

Contrary to the above-mentioned localities, Amsterdam Island (Indian Ocean) has not yet been investigated extensively for testate amoebae, despite its unique and quite interesting geographical position in the context of microbial biogeography. Amsterdam Island and the neighbouring Saint Paul Island are among the most remote islands in the world. Australia, South Africa and Antarctica are located 3200, 4200 and $3300 \mathrm{~km}$, respectively, away from these islands. To our knowledge there has only been one prior study of testate amoebae from Amsterdam Island. Richters (1908) mentioned the presence of four taxa: Difflugia globulosa, Euglypha seminulum (current name: Assulina seminulum Ehrenberg 1848), Nebela collaris and Nebela vas (Apodera vas Certes 1891). Given the size and diversity of habitats on the island, these four taxa obviously represent only a small part of the potential overall testate amoeba diversity of Amsterdam Island. In this study, our aim was to assess the testate amoeba biodiversity of Amsterdam Island and, more generally, to test the hypothesis of their limited distribution.

\section{MATERIALS AND METHODS}

\section{Study site}

Amsterdam Island is located in the Indian Ocean $\left(37^{\circ} 41^{\prime} \mathrm{S}-\right.$ $77^{\circ} 31^{\prime} \mathrm{E}$ ), north of the subtropical convergence (Fig. 1). The volcanic island covers a surface of $55 \mathrm{~km}^{2}$. It is entirely volcanic and constituted of a single cone culminating at $881 \mathrm{~m}$ (Mont de la Dives). It is geologically very young, and probably formed during the past 700,000 years (Giret, 1987). Steep cliffs surround much of the island. The climate is temperate oceanic (Frenot \& Valleix, 1990) with a mean annual temperature of $13.8^{\circ} \mathrm{C}$, and mean temperatures of $11.2^{\circ} \mathrm{C}$ in the coldest month (August) and $17.0^{\circ} \mathrm{C}$ in the warmest month (February) (Caroll, 2003). Relative humidity is generally high (c. $80 \%)$ due to the frequency of low cloud ceilings. Precipitation is usually high, with an annual average of $1114 \mathrm{~mm}$ distributed over 239 days and falling primarily as rain. The austral summer (JanuaryMarch) is drier $\left(78 \mathrm{~mm}\right.$ month $^{-1}$ ) than the other seasons $\left(100 \mathrm{~mm} \mathrm{month}^{-1}\right)$. Permanent water bodies are scarce and restricted to the higher plateau in the centre of the island (Plateau des Tourbières) and the west-south-west part of the island. Almost all other areas have neither permanent nor semi-permanent water bodies due to the steepness of the slopes and the permeability of the lava. Due to high relative humidity, the summit is often foggy, and these conditions have allowed extensive peat development in the volcanic caldera.

On the higher central plateau (Fig. 1), the vegetation has a typical sub-Antarctic character and is dominated by a large number of bryophyte species (including Sphagnum spp.), grasses and small ferns. On the slopes, the vegetation cover becomes thicker with decreasing altitude, with clear changes in the dominant covering species: larger ferns and grasses replace the moss vegetation and gradually the Sphagnum cover also disappears with decreasing altitude (B. Van de Vijver, personal observation). On the lower parts of the island, remnants of the once very extended Phylica arborea Thouars forests can be found. This species is endemic to Amsterdam Island and Tristan da Cunha islands (Richardson et al., 2003). The 


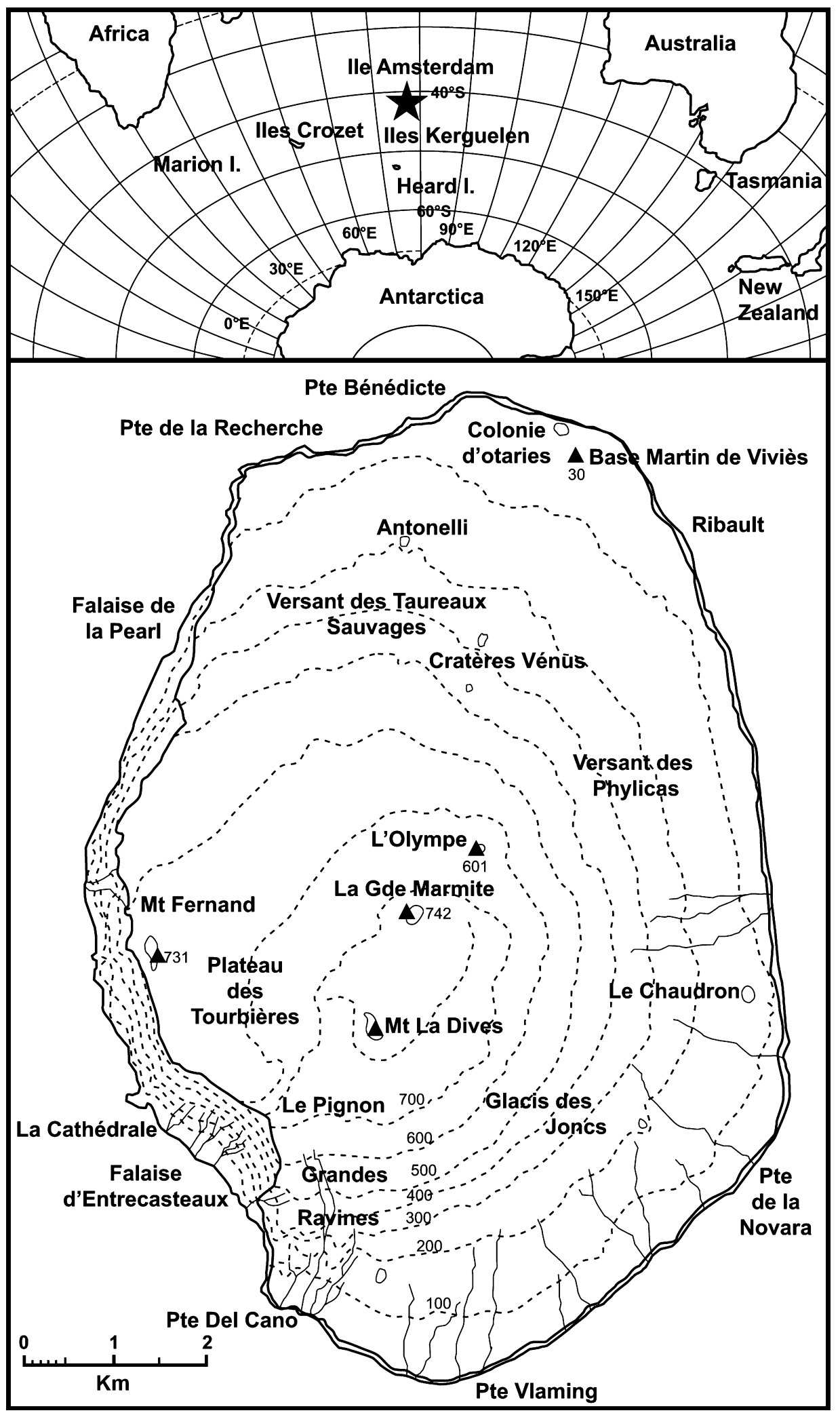

Figure 1 Geographical position of Amsterdam Island in the Southern Indian Ocean and detailed map of the island.

endemic fauna is rather poor and comprises a few marine bird species such as the rare Amsterdam albatross (Diomedea amsterdamensis Roux et al., 1983; Jouventin \& Roux, 1983) and several larger fur seal colonies (Arctocephalus tropicalis Gray). Fires and the introduction of cattle (Bos taurus Linnaeus) on the island have caused major ecological changes. 


\section{T. J. Heger et al.}

The cattle population is now controlled, and parts of the island are recovering. A small, permanently occupied base (Martin de Viviès) is situated on the northern shore.

\section{Sampling}

During two short visits to Amsterdam Island in 1998 and 1999, 83 samples were collected from all over the island, 60 of which were analysed in this study. In order to obtain a broad overview of the diversity and distribution of the testate amoeba communities on the island, samples were taken from different habitat types: freshwater ponds, rivers and mosses (ranging from aquatic to dry terrestrial). Additional sampling was performed during the austral summer of 1999-2000. Samples were fixed in the field with 3\% formaldehyde.

Due to the very short character of the stay during ships' stopovers on the island, only a very limited number of abiotic parameters could be measured. Water $\mathrm{pH}$ was measured using a WTW Multimeter (Wissenschaftlich-Technische Werkstätten GmbH, Weilheim, Germany). Moss moisture values were estimated using the moisture scale by Jung (1936), ranging from $\mathrm{FI}=$ submerged mosses to FVIII $=$ dry - no water. Although this method may seem rather subjective, the moisture classes can be related to real moisture equivalents in percentages (Meisterfeld, 1977).

\section{Testate amoeba analysis}

To extract testate amoebae, samples were shaken energetically in distilled water and passed through a sieve with a mesh diameter of $250 \mu \mathrm{m}$. Testate amoebae were then concentrated by centrifugation $(5 \mathrm{~min}$ at $1125 \times g$ ). Rose Bengal was added to differentiate the test without or with protoplasma (corresponding to dead or living individuals at the moment of sampling). In each sample, 150 testate amoebae were identified at $\times 400$ magnification. After the count of 150 individuals was reached, a short check for potential supplementary species was performed on additional slides. The following taxonomic references were used for identification: Deflandre (1928, 1929, 1936); Decloitre (1962, 1978, 1979, 1981); Grospietsch (1964, 1971); Ogden \& Hedley (1980); Ogden (1983); Vincke (2006).

Because of taxonomic uncertainties in the A. dentistoma complex, we performed a light microscope morphometric analysis (length and width) on 38 specimens of A. dentistoma (sensu lato) from 12 different samples. Investigations on the shell ultrastructure of A. dentistoma were performed by scanning electron microscopy (SEM) on six different specimens from two different samples (numbers 27 and 46). Specimens were isolated using a glass micropipette, positioned on an aluminium stub, then air-dried in a desiccator for 1 week. The samples were coated with gold in a Bal-Tec SCD005 sputter (Bal-Tec AG, Balzers, Liechtenstein). Specimens were observed with a Philips XL30 FEG microscope at a tension of $3 \mathrm{kV}$ (Philips Electron Optics, Eindhoven, the Netherlands).

\section{RESULTS}

\section{Diversity and species composition}

Forty-three taxa (including species, infra-specific taxa and morphotypes of uncertain taxonomic affiliation) belonging to 15 genera were observed in the 60 moss and water samples analysed (Appendices S1 and S2 in Supporting Information). The three most abundant taxa, Trinema lineare, Assulina muscorum and Corythion dubium, together made up 64\% of the total count (Appendix S2), while the relative abundance of each of the 40 other taxa was lower than 5\%. The genera Euglypha and Difflugia showed the highest diversity, with 10 and six taxa, respectively, while the genus Nebela was represented only by Nebela lageniformis. Heleopera sphagni, Difflugia angulostoma and Arcella arenaria were each observed in only a single sample during the screening of samples after the total count of 150 individuals had been reached. Of the 43 taxa recorded, five taxa could not be assigned a precise name based on their morphology: Assulina sp. 1, Cyphoderia sp. 1, Difflugia sp. 3, Difflugia sp. 7 and Euglypha cf. cuspidatum.

\section{Morphological comparisons among the Argynnia dentistoma species complex}

Based on light and SEM observations, the structure and the composition of the Argynnia dentistoma shells from Amsterdam Island samples correspond to the original description of A. dentistoma by Penard (1890). The shells were composed mainly of circular agglutinated scales around the pseudostome and with circular or elongated scales on the rest of the shell (Figs 2a \& 3a-i). The shell ultrastructure differs considerably among individuals due to the high morphological variability of the scales used to build the shell (Fig. 3a-i). The shell of some individuals is even composed of a few large, elongated particles that may consist of agglutinated diatoms (Fig. 3b).

The mean length $(L)$ and width $(W)$ of the specimens observed were $79.2 \pm 1.5$ and $60.1 \pm 1.4 \mu \mathrm{m}$, respectively. As shown in Fig. 4, the range of biometric values is large and overlaps with the corresponding values of $A$. dentistoma from the Czech Republic (Fig. 2b) $(L=96 \pm 1 ; \quad W=64 \pm 1$; $n=10)$ (Lara et al., 2008), A. dentistoma from Marion Island (Fig. 2c) $(L=91.0 \pm 1.0, W=78.1 \pm 0.9 \mu \mathrm{m} ; n=22)$ (Grospietsch, 1971) and $A$. antarctica from Marion Island (Fig. 2d) $(L=78.7 \pm 0.9, \quad W=55.9 \pm 0.8 \mu \mathrm{m} ; n=38)$ (Grospietsch, 1971).

\section{DISCUSSION}

\section{Testate amoeba diversity}

Of the 43 testate amoebae morphotaxa observed in the moss and water samples, three ubiquitous taxa, Trinema lineare, Assulina muscorum and Corythion dubium, dominated the communities. These species, and in particular T. lineare, are frequently reported in the literature as being dominant taxa in 

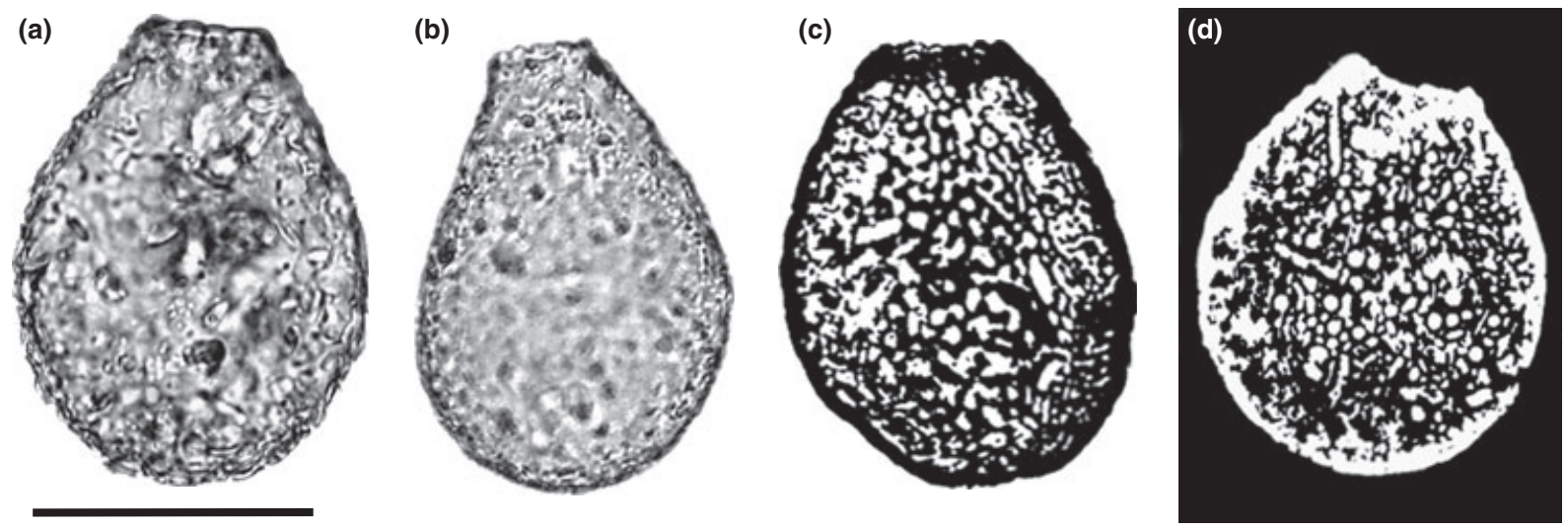

Figure 2 Light microscopy pictures illustrating four different specimens of the Argynnia complex: (a) A. dentistoma, Amsterdam Island, present study; (b) A. dentistoma, Czech Republic (Lara et al., 2008); (c) A. dentistoma, Marion Island (Grospietsch, 1971); (d) A. antarctica, Marion Island (Grospietsch, 1971). Scale bar $=50 \mu \mathrm{m}$.

different environments (Wanner, 1991; Ledeganck et al., 2003; Mattheeussen et al., 2005; Vincke et al., 2006). This ubiquity probably reflects the high reproduction rate and the wide ecological tolerance of this species.

Among the recorded taxa, only two (Assulina seminulum and Difflugia globulosa) had previously been recorded on this island (Richters, 1908), therefore the 41 other taxa represent new records. While our study substantially increases the known diversity of testate amoebae on Amsterdam Island, it is clear that the analysis of 60 samples is not sufficient to find all the taxa living there.

We did not find two of the four species that were previously reported by Richters in 1908: Nebela collaris and Apodera vas. This is surprising, as the environmental preferences of these species correspond well with the nature of the samples (i.e. wet mosses) that were investigated in the present study. Moreover, these taxa are both quite large, so they are unlikely to be overlooked while scanning through the samples after the count of 150 individuals was reached. It is of course possible that both records are the result of a misidentification. Indeed, some misidentifications of $N$. collaris have been reported in the literature. For instance, Penard (1902) mentioned the presence of a probable specimen of Argynnia dentistoma among the N. collaris drawings published by Leidy (1879). In contrast, misidentification of Apodera vas seems unlikely because of the unmistakable morphology of this species (Mitchell \& Meisterfeld, 2005). It is also possible, but less likely, that samples became mixed up or contaminated during the study of Richters (1908). Alternatively, N. collaris and A. vas might have disappeared as a result of ecosystem disturbances resulting in habitat loss. Indeed, Amsterdam Island has been strongly affected by overgrazing and fire during the past centuries (Micol \& Jouventin, 1995; Frenot et al., 2001). However, the suitable habitat for A. vas (wet mosses; Smith \& Wilkinson, 2007) is still present on the top of the island today and certainly never disappeared. Unfortunately, Richters (1908) does not give precise indications on the sampling location, so the former distribution of the two species on the island is unknown. A palaeoecological study based on peat cores from the peatland located on the top of the island would be useful to obtain more insight into the impact of human disturbances on Amsterdam Island and the possible changes in testate amoeba diversity through time.

\section{Taxonomy and biogeography}

Our analyses of shell size variation among Argynnia specimens did not support the morphological distinction of the two species A. antarctica and A. dentistoma, suggested by Grospietsch (1971). Indeed, the size variability of the Argynnia morphotypes collected on Amsterdam Island was continuous, and did not comprise any clusters of individuals with similar sizes (Fig. 4). Furthermore, the length and width of Argynnia specimens from Amsterdam Island bridge the size gaps between A. antarctica and A. dentistoma: the size of the smallest individuals we observed is similar to that of $A$. antarctica from Marion Island (Grospietsch, 1971) and the larger ones are similar in size to A. dentistoma, described by Grospietsch (1971) (Fig. 3). Our size variability reported for A. dentistoma (52-92 $\mu \mathrm{m})$ is also similar to the variability reported in the original species description $(80-130 \mu \mathrm{m}$; Penard, 1890). High variability in shell size is frequently reported for testate amoeba species. For instance, the shell length of Apodera vas ranges from 90 to $210 \mu \mathrm{m}$ (Smith \& Wilkinson, 2007). Similarly, Lahr \& Lopes (2007) reported a $3.4 \times(100-340 \mu \mathrm{m})$ range in test height for Netzelia wailesi. This level of morphological variability generally suggests the existence of more than one taxon. Unfortunately, there are no molecular data to assess if testate amoeba taxa with such high morphological variability are composed of one or more taxa.

In support of the possible variability of testate amoeba morphology, Chardez (1989) and Wanner (1999) showed, using clonal cultures, that abiotic and biotic environmental factors, such as food source, temperature and insecticides, affected the test morphology of several testate amoeba species. 
(a)
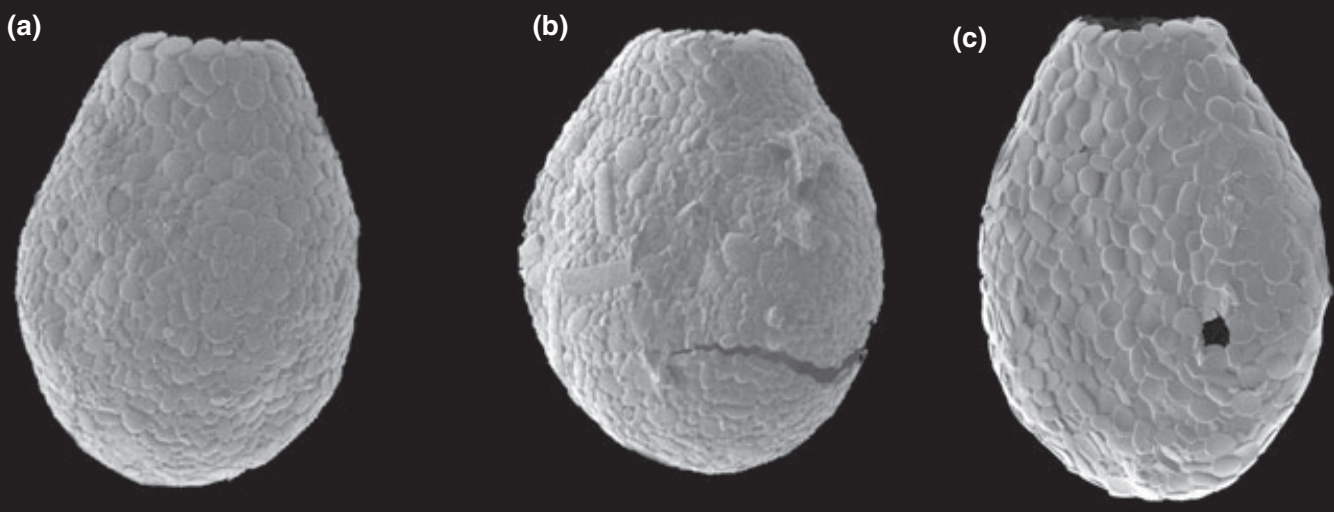

(c)

(d)

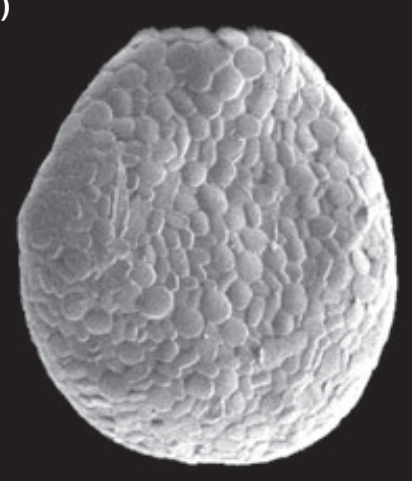

(e)

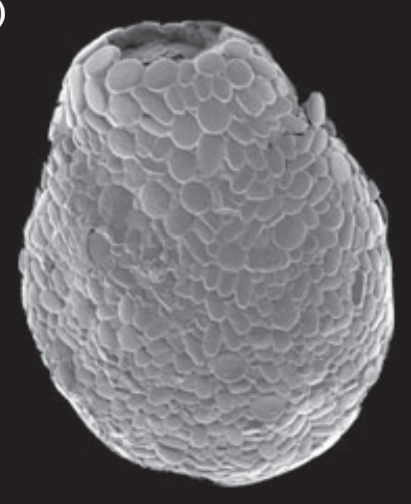

(f)

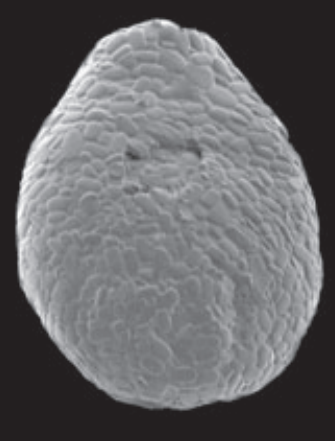

(g)

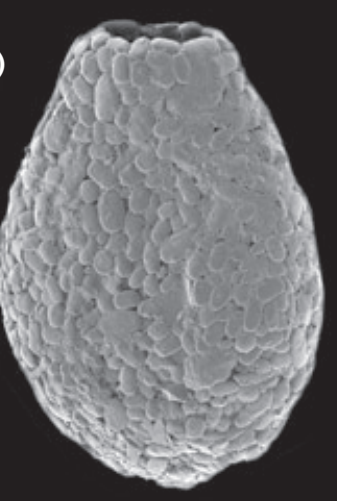

(h)

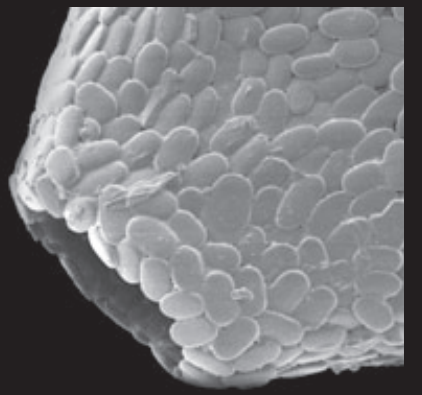

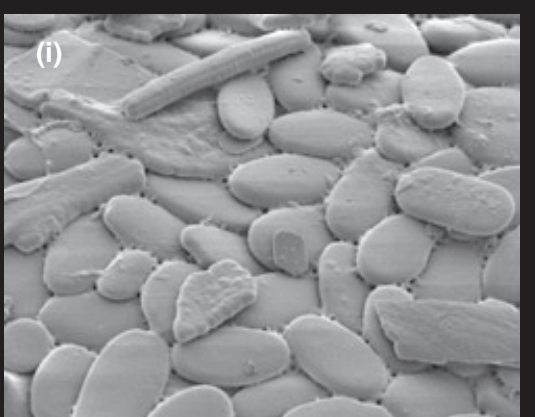

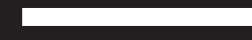

Figure 3 Scanning electron microscopy pictures illustrating different specimens of Argynnia dentistoma from Amsterdam Island (a-g) with detailed pictures of the pseudostome (h) and the shell ultrastructure (i). Scale bars of a-g, h, i = 50, 20 and $10 \mu \mathrm{m}$, respectively.

These studies suggest that some taxa, at least, may also show considerable morphological diversity in the environment.

Our morphometric data contrast with recent evidence for good correspondence between genetic and morphological diversity in Nebelid testate amoebae. Indeed, significant genetic differences in the nuclear $18 \mathrm{~S}$ ribosomal RNA gene were found in two cases between a given taxon and another one that had been described as a variety: (1) Nebela penardiana 
Figure 4 Shell morphometric measurements of four different morphospecies of the Argynnia dentistoma complex: diamonds, A. dentistoma, Amsterdam Island, present study $(n=38)$; triangles, A. dentistoma, Marion Island (Grospietsch, 1971) $(n=22)$; open circles, $A$. antarctica, Marion Island (Grospietsch, 1971) ( $n=38)$; closed circles, A. dentistoma (Lara et al., 2008) $(n=10)$.

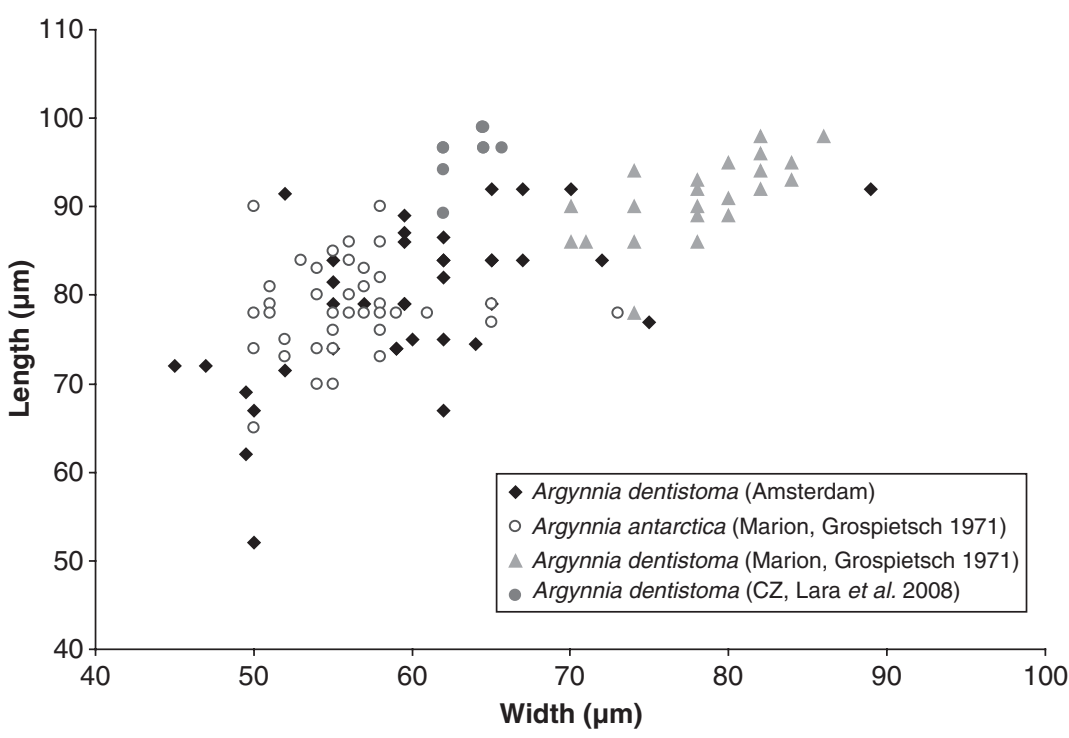

var. minor and N. penardiana, and (2) Nebela tincta var. major and N. tincta (Lara et al., 2008). In both cases, the morphological differences between the two varieties are comparable with the range of sizes and shapes described within the A. dentistoma complex. If the same correspondence exists between morphological and molecular differences within the A. dentistoma complex, a molecular study of this complex could reveal more than one valid taxon, which may have restricted distribution.

Clearly, the morphological data do not allow an unambiguous determination of the biogeographical status of A. dentistoma on Amsterdam Island. Given the observed high morphological variability, it remains possible that a significant genotypic diversity exists within the A. dentistoma complex. A more detailed taxonomic study of the A. dentistoma species complex, based on both morphological and molecular approaches, is needed to clarify the potential validity and endemic status of $A$. antarctica. Until this is done, we consider $A$. antarctica to be an invalid taxon and A. dentistoma to be cosmopolitan. On the other hand, five morphotaxa could not be identified with certainty and might represent new species, potentially with limited distribution.

Several endemic higher plant species have been described on Amsterdam Island, such as Plantago stauntonii (Ronsted et al., 2002). The Amsterdam albatross, Diomedea amsterdamensis, breeds only on a small part of the island and is considered one of the rarest birds in the world (Micol \& Jouventin, 1995). Moreover, at least one endemic insect species exists (Bameul et al., 1990).

The only microbial group investigated in depth on Amsterdam Island to date is that of the non-marine diatoms (Bacillariophyta). Although the non-marine diatom flora was at first considered to be cosmopolitan (Van de Vijver \& Beyens, 1999), the recent description of several species now suggests that an endemic diatom flora is present on the island
(Van de Vijver et al., 2008; M. Cantonati, B. Van de Vijver and $\mathrm{H}$. Lange-Bertalot, unpublished data).

The occurrence of these endemic organisms demonstrates that despite being geologically young $(0.69 \mathrm{Ma}$, according to Giret, 1987), Amsterdam Island is sufficiently old and isolated for speciation to occur within both macroscopic and microscopic organisms. The presence of several biogeographical barriers in the ocean, such as the sub-Antarctic divergence between Amsterdam Island and the islands of the coldtemperate sub-Antarctic region (Stonehouse, 1982), increase the possibility of the development of an endemic (micro-) fauna and flora.

\section{CONCLUSIONS}

In contrast to other taxonomic groups, our data do not provide any conclusive evidence for the existence of endemism among testate amoebae, therefore they would rather bring support to the idea that microorganisms are (at least mostly) cosmopolitan. More than $95 \%$ of the morphospecies (41 of 43) recorded on Amsterdam Island have already been mentioned by Vincke et al. (2004a,b,c) and Vincke (2006) on Îles Crozet and South Georgia, despite the considerable geographical distance between these three sites (Fig. 1). This suggests that the probability of the existence of local endemic species is indeed small. Although Amsterdam Island is very remote, the morphology-based testate amoeba records suggest a lack of speciation. If true, this would mean that biogeographical patterns differ between diatoms and testate amoebae. This would be surprising because there is a priori no major difference in the dispersal potential of these two groups of protists.

Our data do not rule out completely the possible existence of endemic testate amoebae. Indeed, as the taxonomic status of several taxa recorded by Vincke et al. (2004a,b,c) and Vincke (2006) on Îles Crozet and South Georgia, and in this study, is 
not yet established, no definitive conclusion can be drawn regarding their biogeography. The case of the A. dentistoma complex discussed here illustrates this problem. Finally, cryptic diversity has recently been discovered in several free-living protist morphospecies (de Vargas et al., 1999; Slapeta et al., 2005; Finlay et al., 2006). Each of these hidden species can have either restricted or cosmopolitan distributions. An assessment of genetic diversity among and within morphotaxa in relation to geographical distance for some common testate amoebae should be given high priority in order to allow better interpretation of morphology-based testate amoeba distribution data. Only when such data become available will we be able to reach firmer conclusions about the geographical distribution of this very common, but still relatively understudied, group of organisms.

\section{ACKNOWLEDGEMENTS}

Funding to T.H. and E.M. by Swiss NSF project no. 205321109709/1 and PBELP2-1229991, and CCES projects RECORD and BigLink, is acknowledged. Sampling was made possible thanks to the logistics and financial support of the Institut Polaire Paul-Emile Victor in the framework of the terrestrial ecology project 136 (Marc Lebouvier and Yves Frenot). Claude Chaufriasse made the sampling possible. The authors also wish to thank Tanja Schwander for fruitful comments on the manuscript, Niek Gremmen (Data-Analyse Ecologie) for help with moss identifications, and Sven Bellanger for graphical assistance. We also thank Fabienne Bobard and Marco Cantoni at the Interdisciplinary Centre for Electron Microscopy at the EPFL (École Polytechnique Fédérale de Lausanne) for help with the SEM.

\section{REFERENCES}

Bameul, F., Frenot, Y., Lebouvier, M. \& Voisin, J.-F. (1990) Présence de Cercyon (s. str.) depressus Stephens dans l'île Amsterdam (Océan Indien) [Col. Hydrophilidae]. Bulletin de la société entomologique de France, 94, 308.

Beyens, L., Chardez, D., De Baere, D. \& Verbruggen, C. (1995) The aquatic testate amoebae fauna of the Strømness Bay area, South Georgia. Antarctic Science, 7, 3-8.

Bonnet, L. (1981) Thécamoebiens (Rhizopoda Testacea). Biologie des sols 48 (ed. by J. Travé), pp. 23-32. Comité National Francais des Recherces Antarctiques, St Etienne.

Caroll, P. (2003) Amsterdam and Saint Paul Islands, South Indian Ocean. Available at: http://www.btinternet.com/ sa_sa/ amsterdam/amsterdam.html.

Chardez, D. (1989) On the multiplication of Centropyxis discoides and the medium influence on the morphology of the test (Rhizopoda, Testacea). Acta Protozoologica, 28, 31-34.

Decloitre, L. (1962) Le genre Euglypha Dujardin. Archiv für Protistenkunde, 106, 51-100.

Decloitre, L. (1978) Le genre Centropyxis I (Compléments à jour au 31 décembre 1974 de la Monographie du genre parue en 1929). Archiv für Protistenkunde, 120, 63-85.
Decloitre, L. (1979) Le genre Centropyxis II (Compléments à jour au 31.12.1974 de la monographie de 1929). Archiv für Protistenkunde, 121, 162-192.

Decloitre, L. (1981) Le genre Trinema Dujardin, 1841 (Révision à jour au 31.12.1979). Archiv für Protistenkunde, 124, 193-218.

Deflandre, G. (1928) Deux genres nouveaux de Rhizopodes testacés. Annales de Protistologie, 1, 37-43.

Deflandre, G. (1929) Le genre Centropyxis Stein. Archiv für Protistenkunde, 67, 322-375.

Deflandre, G. (1936) Etude monographique sur le genre Nebela Leidy. Annales de Protistologie, 5, 201-286.

Finlay, B.J. \& Clarke, K.J. (1999) Ubiquitous dispersal of microbial species. Nature, 400, 828.

Finlay, B.J., Esteban, G.F., Olmo, J.L. \& Tyler, P.A. (1999) Global distribution of free-living microbial species. Ecography, 22, 138-144.

Finlay, B.J., Esteban, G.F., Clarke, K.J. \& Olmo, J.L. (2001) Biodiversity of terrestrial protozoa appears homogeneous across local and global spatial scales. Protist, 152, 355-366.

Finlay, B.J., Esteban, G.F., Brown, S., Fenchel, T. \& HoefEmden, K. (2006) Multiple cosmopolitan ecotypes within a microbial eukaryote morphospecies. Protist, 157, 377-390.

Foissner, W. (1997) Global soil ciliate (Protozoa, Ciliophora) diversity: a probability-based approach using large sample collections from Africa, Australia and Antarctica. Biodiversity and Conservation, 6, 1627-1638.

Foissner, W. (1998) An updated compilation of world soil ciliates (Protozoa, Ciliophora), with ecological notes, new records, and descriptions of new species. European Journal of Protistology, 34, 195-235.

Foissner, W. (1999) Protist diversity: estimates of the nearimponderable. Protist, 150, 363-368.

Foissner, W. (2006) Biogeography and dispersal of microorganisms: a review emphasizing protists. Acta Protozoologica, 45, 111-136.

Foissner, W. (2008) Protist diversity and distribution: some basic considerations. Biodiversity and Conservation, 17, 235242.

Frenot, Y. \& Valleix, T. (1990) Carte des sols de l'île Amsterdam. Comité National Français des Recherches Antarctiques, 58, 1-49.

Frenot, Y., Gloaguen, J.C., Masse, L. \& Lebouvier, M. (2001) Human activities, ecosystem disturbance and plant invasions in subantarctic Crozet, Kerguelen and Amsterdam Islands. Biological Conservation, 101, 33-50.

Giret, A. (1987) Géologie des Iles Australes Françaises. Comité National Français des Recherches Antarctiques, 58, 17-41.

Grospietsch, T. (1964) Die Gattungen Cryptodifflugia und Difflugiella (Rhizopoda Testacea). Zoologischer Anzeiger, 172, 243-257.

Grospietsch, T. (1971) Rhizopoda - Beitrag zur Ökologie der testaceen Rhizopoden von Marion Island. Marion and Prince Edward Islands (ed. by E.M. van Zinderen-Bakker, J.M. Winterbottom and R.A. Dyer), pp. 411-419. A.A. Balkema, Cape Town. 
Jouventin, P. \& Roux, J.P. (1983) Ornithology - discovery of a new albatross. Nature, 305, 181.

Jung, W. (1936) Thecamöben ursprünglicher, lebender deutscher Hochmoore. Abhandlungen aus dem Landesmuseum für Naturkunde zu Münster in Westfalen, 7, 1-87.

Lahr, D.J.G. \& Lopes, S. (2007) Ultra-structure and biometry of three lobose testate amoebae of the family Lesquereusiidae (Tubulinea : Arcellinida) based on specimens from Sao Paulo, Brazil. Acta Protozoologica, 46, 339-348.

Lara, E., Heger, T.J., Ekelund, F., Lamentowicz, M. \& Mitchell, E.A.D. (2008) Ribosomal RNA genes challenge the monophyly of the Hyalospheniidae (Amoebozoa: Arcellinida). Protist, 159, 165-176.

Ledeganck, P., Nijs, I. \& Beyens, L. (2003) Plant functional group diversity promotes soil protist diversity. Protist, 154, 239-249.

Leidy, J. (1879) Fresh-water rhizopods of North America. Report of the United States Geological Survey of the Territories, 12, 1-324.

Mattheeussen, R., Ledeganck, P., Vincke, S., Van de Vijver, B., Nijs, I. \& Beyens, L. (2005) Habitat selection of aquatic testate amoebae communities on Qeqertarsuaq (Disko Island), West Greenland. Acta Protozoologica, 44, 253-263.

Meisterfeld, R. (1977) Horizontal and vertical distribution of Testacea (Rhizopoda, Testacea) in Sphagnum. Archiv fur Hydrobiologie, 79, 319-356.

Micol, T. \& Jouventin, P. (1995) Restoration of Amsterdam Island, South Indian Ocean, following control of feral cattle. Biological Conservation, 73, 199-206.

Mitchell, E.A.D. \& Meisterfeld, R. (2005) Taxonomic confusion blurs the debate on cosmopolitanism versus local endemism of free-living protists. Protist, 156, 263-267.

Ogden, C.G. (1983) Observations on the systematics of the genus Difflugia in Britain (Rhizopoda, Protozoa). Bulletin of the Natural History Museum. Zoology Series, 44, 1-73.

Ogden, C.G. \& Hedley, R.H. (1980) An atlas of freshwater testate amoebae. British Museum (Natural History), London and Oxford University Press, Oxford.

Penard, E. (1890) Études sur les Rhizopodes d'eau douce. Mémoires de la Société de Physique d'Histoire Naturelle de Genève, 31, 1-230.

Penard, E. (1902) Les Rhizopodes du bassin du Léman. Kündig, Genève.

Penard, E. (1911) Sarcodina. Rhizopods d'eau douce, British Antarctic Expedition, 1907-1909. Reports on the scientific investigations. Biology, Vol. 1 (ed. by J. Murray), pp. 203262. William Heinemann, London.

Richardson, J.E., Fay, M.F., Cronk, Q.C.B. \& Chase, M.W. (2003) Species delimitation and the origin of populations in island representatives of Phylica (Rhamnaceae). Evolution, 57, 816-827.

Richters, F. (1908) Die Fauna der Moosrasen des Gaussbergs und einiger südlicher Inseln. Deutsche Südpolar Expedition, 9, 259-302.

Ronsted, N., Chase, M.W., Albach, D.C. \& Bello, M.A. (2002) Phylogenetic relationships within Plantago (Plantaginaceae): evidence from nuclear ribosomal ITS and plastid trnL-F sequence data. Botanical Journal of the Linnean Society, 139, 323-338.

Sabbe, K., Verleyen, E., Hodgson, D.A., Vanhoutte, K. \& Vyverman, W. (2003) Benthic diatom flora of freshwater and saline lakes in the Larsemann Hills and Rauer Islands, East Antarctica. Antarctic Science, 15, 227-248.

Slapeta, J., Moreira, D. \& López-García, P. (2005) The extent of protist diversity: insights from molecular ecology of freshwater eukaryotes. Proceedings of the Royal Society B: Biological Sciences, 272, 2073-2081.

Smith, H.G. (1982) The terrestrial protozoan fauna of South Georgia. Polar Biology, 1, 173-179.

Smith, H.G. \& Wilkinson, D.M. (2007) Not all free-living microorganisms have cosmopolitan distributions - the case of Nebela (Apodera) vas Certes (Protozoa: Amoebozoa: Arcellinida). Journal of Biogeography, 34, 1822-1831.

Stoeck, T., Bruemmer, F. \& Foissner, W. (2007) Evidence for local ciliate endemism in an Alpine anoxic lake. Microbial Ecology, 54, 478-486.

Stonehouse, B. (1982) La zonation écologique sous les hautes latitudes australes. CNFRA, 51, 531-537.

Van de Vijver, B. \& Beyens, L. (1999) First contribution to the diatom flora of the Amsterdam Island (TAAF). Annales de Limnologie - International Journal of Limnology, 35, 8594.

Van de Vijver, B., Beyens, L. \& Lebouvier, M. (2008) The genus Eunotia on the volcanic island, Île Amsterdam (Southern Indian Ocean). Nova Hedwigia, 87, 113128.

de Vargas, C., Norris, R., Zaninetti, L., Gibb, S.W. \& Pawlowski, J. (1999) Molecular evidence of cryptic speciation in planktonic foraminifers and their relation to oceanic provinces. Proceedings of the National Academy of Sciences USA, 96, 2864-2868.

Vincke, S. (2006) Diversity and ecology of the testate amoebae fauna of île de la Possession. Thesis, Antwerp, Belgium.

Vincke, S., Gremmen, N., Beyens, L. \& Van de Vijver, B. (2004a) The moss dwelling testacean fauna of Île de la Possession. Polar Biology, 27, 753-766.

Vincke, S., Ledeganck, P., Beyens, L. \& Van de Vijver, B. (2004b) Soil testate amoebae from sub-Antarctic Îles Crozet. Antarctic Science, 16, 165-174.

Vincke, S., van de Vijver, B., Mattheeussen, R. \& Beyens, L. (2004c) Freshwater testate amoebae communities from île de la Possession, Crozet Archipelago, Subantarctica. Arctic Antarctic and Alpine Research, 36, 584-590.

Vincke, S., de Vijver, B.V., Gremmen, N. \& Beyens, L. (2006) The moss dwelling testacean fauna of the Strømness Bay (South Georgia). Acta Protozoologica, 45, 65-75.

Vyverman, W., Verleyen, E., Sabbe, K., Vanhoutte, K., Sterken, M., Hodgson, D.A., Mann, D.G., Juggins, S., De Vijver, B.V., Jones, V., Flower, R., Roberts, D., Chepurnov, V.A., Kilroy, C., Vanormelingen, P. \& De Wever, A. (2007) Historical processes constrain patterns in global diatom diversity. Ecology, 88, 1924-1931. 
Wanner, M. (1991) Studies on the ecology of testate Amoebae (Protozoa, Rhizopoda) in forests of southern Germany. Archiv für Protistenkunde, 140, 237-288.

Wanner, M. (1999) A review on the variability of testate amoebae: methodological approaches, environmental influences and taxonomical implications. Acta Protozoologica, 38, 15-29.

Wilkinson, D.M. (1994) A review of the biogeography of the protozoan genus Nebela in the southern temperate and Antarctic zones. Area, 26, 150-157.

Wilkinson, D.M. (2001) What is the upper size limit for cosmopolitan distribution in free-living microorganisms? Journal of Biogeography, 28, 285-291.

Wilkinson, D.M. \& Smith, H.G. (2006) An initial account of the terrestrial protozoa of Ascension Island. Acta Protozoologica, 45, 407-413.

\section{SUPPORTING INFORMATION}

Additional Supporting Information may be found in the online version of this article:
Appendix S1 Locations and characteristics of all samples of testate amoebae analysed.

Appendix S2 List of all testate amoebae observed.

Please note: Wiley-Blackwell is not responsible for the content or functionality of any supporting materials supplied by the authors. Any queries (other than missing material) should be directed to the corresponding author for the article.

\section{BIOSKETCH}

Thierry Heger is a PhD student at the Swiss Federal Research Institute WSL, and is also affiliated to EPFL (École Polytechnique Fédérale de Lausanne) and Universities of Neuchâtel and Geneva, Switzerland. His research focuses on the ecology, phylogeny and biogeography of testate amoebae.

Editor: John Lambshead 